\title{
End User Satisfaction and Individual Performance Assessments in e-Procurement Systems
}

\author{
Manal M. N. Sharabati, Ainin Sulaiman, and Noor Akma Mohd Salleh
}

\begin{abstract}
End-user satisfaction and individual performance have been identified by many researchers as critical determinants of the success of information systems. As an escalating number of organizations now utilize e-procurement systems, there is a desire to understand their effect on individual end-user's performance. Therefore, this research attempts to empirically examine a framework identifying the relationships between end-user satisfaction, and individual end-user performance, in addition to assessing the impact of three proposed antecedents of end-user satisfaction: processing, content and usability. Data gathered from 432 end-users of ePerolehan system in the Malaysian government agencies were utilized to examine the relationships proposed in the framework using the Partial least square (PLS) approach. The findings provide strong support for our model. Our results indicate three factors processing, content and usability significantly affect end-user satisfaction, while the higher levels of end-user satisfaction leads to improved individual performance.
\end{abstract}

Index Terms-E-procurement, user satisfaction, individual performance.

\section{INTRODUCTION}

Most organizations regardless whether they are private or public sector are now using information system (IS), particularly the Internet. As such both these sectors have become IT-enabled. One of the IT enabled system is the e-Procurement system. Many organizations are using e-Procurement. The same can be said for government e-Procurement. Goldfinch [1] points out that the chance to succeed in e-Government projects is only $30 \%$. The same percentage is applicable to the government e-Procurement system as part of the integral component of e-Government project [2]. As such, Government needs to evaluate the success factors that can assist them to successfully perform government projects. Most of government projects are highly scaled and costly, thus successful implementation of the government e-procurement systems is essential.

The IS literature considers a system to be effective or successful when it encompasses return on investment, elevates organizational productivity, improves outcome

Manuscript received July 22, 2014; revised September 10, 2014.

The authors are with the Department of Operations and Management Information System, Faculty of Business and Accountancy, University of Malaya, 50603 Kuala Lumpur, Malaysia (e-mail: manals@gmail.com, ainins@um.edu.my, akmasalleh@um.edu.my) quality, increases user satisfaction, and sustains use by organizational employees [3]. DeLone and McLean [4] propose an IS success model by distinguishing six dimensions of IS success, that include system quality, information quality, information use, user satisfaction, individual impact and organizational impact. For example, user satisfaction is found to be a crucial determinant of system success and effectiveness [4], [5].

Therefore, success of a system is considered to be the extent to which a presented IS essentially makes a contribution to achieving business objectives [6]. Evaluating the success of systems within businesses is certainly recognized as the single most critical issue of IS management discipline [7]. IS Scholars use various techniques to assess systems' success such as investigating success of a system via the system usage, user satisfaction and other categories of performance [5], [8], [9]. Interestingly, many prior literature note user satisfaction to be a surrogate measure for system success, and have use user satisfaction to assess the success implementation of a IS [10]-[13]. As such, this paper uses user satisfaction as a measure to assess the successful implementation of government e-Procurement. Prior studies have indicated that user satisfaction can be influenced by numerous factors, such as perceived ease of use [14], [15], service quality [16], [17], and perceived usefulness [18], [19]. However, this study confines to factors that relate to the support and provisions of the e-Procurement system itself that focus on the processing, content and usability of the e-procurement systems by internal users (i.e., employees). Moreover, this study focused on the mandatory IS [20], which is still scarce in studies on system success or failure [21]-[23].

The aim of this paper is to identify the relationship between user satisfaction and individual performance. In addition, this study also aims to verify whether processing, content and usability influences user satisfaction.

\section{LITERATURE REVIEW}

\section{A. Theoretical Background}

The impact of IS on individual performance indicates the actual performance of the user of a specific IS [24]. DeLone and McLean [4] state that user performance impact is also a sign that the given IS has provided the user a good knowledge of the decision context, has enhanced the user productivity, or has evolved his or her perception of the value or effectiveness of the IS. End-user satisfaction is among the most favored indicator of success of an information system [4]. The common argument of the user satisfaction approach is the fact that higher level of user satisfaction leads to higher 
level of user performance [25]. Over the last decade, there have been several attempts to anticipate the satisfaction of users towards IS implementation. Several researchers attempts to find out the factors of the IS that cause maximum user performance through user satisfaction [4], [24], [26]. Nevertheless, it can be clearly seen that most of the existing studies concentrates on IS that are used on a voluntary usage, rather than mandatory usage. Thus, the suitability of previous findings in the context of mandatory use remains unclear [27], and require deeper analysis. In a mandatory usage scenario, user satisfaction is relatively very important as indicator of success [20]. For example, Brown, Massey [20] mention that the dependent variable "use" is not suitable in mandatory use context; and recommended replacing it with satisfaction variable. Lu, Wang [28] point out that when an organization forces its users to use a particular system, greater emphasis should be placed upon usage satisfaction.

User satisfaction is one of the well-known concepts in organizational psychology, and researchers have defined this concept in various ways. Au et al.[29] define user satisfaction as the sum of experiences that user acquires from his/her interaction with the technology over time, and represent users' cognitive evaluation of the entire IS user experience. In this study, the researcher considers users' satisfaction as the main outcome of a mandated e-Procurement system by government, and thus based on Venkatesh, Morris [30] work, investigate a set of antecedents to satisfaction, which indicates that there is a positive correlation between technology perception and user acceptance. Departing from this notion, this paper attempts to examine three variables: perceived processing, perceived content and perceived usability.

\section{B. The Research Model}

Fig. 1 presents the research model created in this study. The research model suggests that end-user satisfaction will have a positive direct impact on individual performance. In addition, end-users satisfaction is influenced by three constructs: processing, content and usability. In line with the literature review, we propose and test four hypotheses addressing (a) the relationship between processing and end-user satisfaction, (b) the relationship between content and end-user satisfaction, (c) the relationship between usability and end-user satisfaction, and (d) the relationship between end-user satisfaction and individual performance.

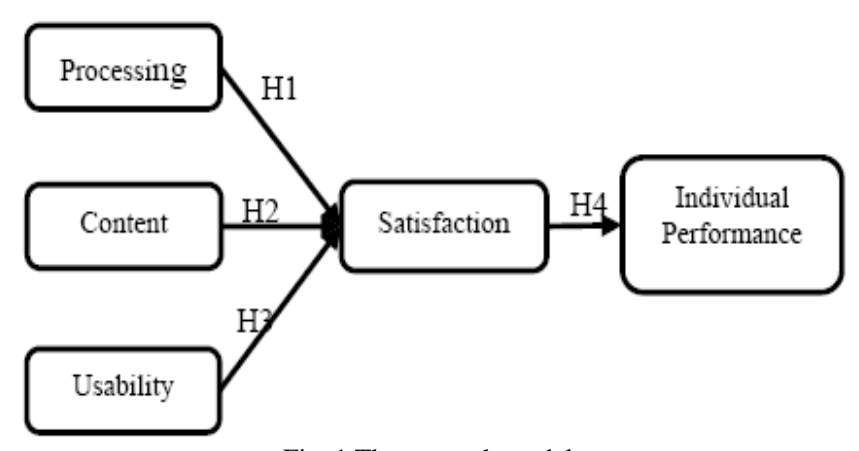

Fig. 1 The research model.

\section{Factors Influencing User Satisfaction}

There are many factors that influence users' satisfaction.
However there are three that is related to the systems functionality i.e. processing, content and usability of the systems [4], [31], [32].

Processing refers to the degree to which system users experience system capability to manipulate, deal, and execute procurement transactions from placing an order until it reaches the supplier [33]. Saeed, Malhotra [34] points out that inter-organizational systems (e.g., e-procurement systems) facilitate the exchange and the process of the information; therefore, the time information substitute the old manual functions. Moreover; e-procurement systems facilitate the execution of complex orders, Brandon-Jones and Carey [33] claimed that user perception of complex order processing quality can be experienced by system speed, accuracy, and capability. Electronic processing provides organizations with a better chance to leverage the lead-time and the accuracy of the information [35]-[37], and it eliminates paper documents and improves the speed of order approval and processing [38]. At the same time, the use of e-catalogue reduces processing time needed to place an order [39]; consequently, using e-procurement systems decrease user compliant by minimizing errors and improving the match between user need and products received [40]. Zhou and Benton $\mathrm{Jr}$ [41] stated that in order to improve organizational performance and thus users satisfaction, organizations should leverage their dynamism by increasing information processing capacity. System processing influences user satisfaction when, "the perception of users that the system effectively meets their business demands" [40]. [40] mentioned that user satisfaction can be enhanced by several factors one of them a user need fulfilment, thus delay and errors in processing orders will negatively affect user satisfaction.

H1: User satisfaction is positively influenced by e-procurement system processing.

Content refers to the degree of which a system user experiences the availability and the accuracy of the needed information in the system and the level of effort required to get it [33], [42]. Information content determines the value of the information displayed to the system user in the report or inquiry screens and the precision and completeness of the information [43]. System users should be provided with the appropriate content that facilitates their work, and they have to access the content easily by using friendly search tools [33]. In e-procurement system discipline, in addition to the re-designing of the procurement process, content organization is another essential factor for successful e-procurement system implementation [44]. The principle concept of e-procurement system is to involve the end-user during the procurement process through a multi-supplier e-catalogue which reduces procedure replication like re-entry of data in the supply chain for requested products or services. Therefore, the provision of product information is crucial in e-procurement. $\mathrm{Gu}$, Konana [45] remarked that low quality information is unproductive since it wastes users' time searching and increases information processing costs. In addition, out-of-date content make it more challenging for users to locate valuable and useful information [46]. Maditinos and Theodoridis [47] found that product information quality influence customer satisfaction. 
H2: User satisfaction is positively influenced by e-procurement system content.

Usability refers to "the perceived ease of use and navigation around an e-Procurement System" [33]. If a mandatory system is troublesome to use, then users will probably be disappointed, and experience the degree of required efforts to be relatively high, when contrarily, the perceived effort needed to use a mandatory system should be minimal [48]. Bias and Mayhew [49] state that usability improves user satisfaction and productivity, while Kim and Eom [50] determined that usability is of a magnitude of significance in forming user satisfaction. Zhang and Galletta [51] posited that the main aim of IS Interaction is to boost the usability of systems.

H3: User satisfaction is positively influenced by perceived usability.

\section{End-User Satisfaction and Individual Performance}

Earlier research provided empirical evidences about the positive impact of user satisfaction on individual performance [52]-[54]. For instance, Guimaraes and Igbaria [53] discovered that end user satisfaction has significant relationship on end-user job performance in server/client.in addition, Hou [24] found that user satisfaction has strong direct influence on users performance in business intelligence systems context. Moreover, DeLone and McLean [4] mentioned the possible influence of user satisfaction on users performance. Thus, this study proposes that end users satisfaction would have a significant positive influence on individual performance.

H4: Individual performance is positively influenced by end-user satisfaction.

\section{RESEARCH DESIGN AND METHOD}

\section{A. Respondents and Data Collection}

This study applies the cross-sectional empirical research design in order to examine the factors that influences end user satisfaction in a mandatory system environment.

The popularity of e-procurement system practices is increased due to its huge benefits. Referring to e-procurement systems literature, many studies provide evidence of the benefits of implementing e-procurement system and its impacts on the private and public organizations [3], [55]. Many firms experienced e-procurement systems and due to its efficiency and effectiveness, most of them are satisfied with its performance [56]. Recently, e-procurement system is considered as a significant means in business. It improves communications between buyer and suppliers, reduces transaction and administration costs, provides wider base of buyers and suppliers, improves delivery and logistic functions, and reduce paper-base work [37], [55]. In the same vein, the Malaysian government implemented e-Government technologies to fulfill the aim of enhancing internal government operations, as well as external services to Malaysian citizens and businesses [57]. Among the application introduced was the ePerolehan. It was first introduced in 2000 and is an end-to-end, multi-buyer, multi-supplier e-procurement system that allows Government Agencies across Malaysia to electronically purchase products and services from both local and international suppliers. It employs online technologies to connect Malaysia's Government Agencies and Suppliers all over the world into a digital transacting environment [58]. ePerolehan offers and switches traditional manual procurement procedures into an electronic procurement system [58]. The use of the ePerolehan system is mandated among system users in all the government Ministries, agencies and departments. It was reported that the system recorded up to RM14 billion (US\$4.6) in transactions [59]. For this study, the participants are employees that are users of the ePerolehan system in Malaysian Government and agencies the participants are direct users of the system who are working in purchasing departments. The direct users of the system are the suitable respondents to this study, because they interact directly with the system; therefore, they have the ability to express their perceptions of the system.

The empirical data for this study was collected by using survey questionnaire. A questionnaire that reflects the proposed framework constructs was developed to collect the primary data for the study. A seven-point Likert scale ranging from (1) strongly disagrees to (7) strongly agree was employed to rate the extent to which respondents agree to the statements. Pre-testing for the questionnaire was conducted to confirm the face and content validity by panel of experts in IS field and their necessary suggestions were taken into consideration. Pilot study was collected and primary internal consistency was investigated to ensure the reliability of the proposed constructs. A total of 1000 e-Perolehan system end-users were randomly selected to voluntarily complete a confidential questionnaire. 442 e-Perolehan end users returned the questionnaire yielding a response rate of $44.2 \%$. Of these, only 432 were completed questionnaires were complete and useable, with the final response rate of $43.2 \%$.

\section{B. Measures of the Constructs}

The research model contains five constructs; one dependent construct, one mediating construct and three independent constructs. All constructs' measurements are adopted from previous studies. Individual performance is a dependent construct, its measurements are adopted from Igbaria and Tan [52] and Kositanurit, Osei-Bryson [25].User's satisfaction is a mediating construct, its measurements are adopted from Palvia [60] and Wixom and Todd [61]. The three independent constructs are: perceived processing, and its measures are adopted from Brandon-Jones and Carey [33]; perceived content and its measures are adopted from Brandon-Jones and Carey [33] and Hou [24]; perceived usability with measures that are adopted from Brandon-Jones and Carey [33] and Davis [62] (see Appendix).

\section{DATA ANALYSIS AND RESUltS}

SmartPLS 2.0.M3 is used as the main statistical analysis tool to purify the measurement items and test the hypothetical relationship. 


\section{A. Measurement Model}

To assess the reliability and validity of constructs, confirmatory factor analysis is performed. Factor cross loading shows that all items are loading on their construct more than other constructs, the loading of each item on its construct is more than $(0.70)$ (see Table I).

All the constructs were tested for reliability by using composite reliability and Cronbach's alpha. Compared to Cronbach's alpha, Composite reliability is acknowledged as a more rigorous assessment of reliability [63]. As shown in Table II, the result of composite reliability and Cronbach's Alpha for all constructs were greater than (0.80), which indicates that all construct measures are reliable. Constructs validity were assessed by investigating the convergent and discriminant validities. Convergent validity was evaluated by the average variance extracted (AVE) values. As demonstrated in Table II, the AVE for all constructs is more than the threshold value of (0.50) [64]. Furthermore, discriminant validity is evaluated by comparing the square root of AVE values for each construct, with the correlation values located between the construct and other constructs [63]. As illustrated in Table III, all square roots of AVEs are larger than constructs correlations, implying that the variance outlined by the particular construct is greater than the measurement error variance. Thus, all constructs demonstrated an acceptable level of convergent validity and discriminant validity.

TABLE I: FACTORS CROSS LOADING

\begin{tabular}{|c|c|c|c|c|c|}
\hline & IPP & SAT & CNT & PRS & USB \\
\hline IPP1 & $\mathbf{0 . 8 9 4}$ & 0.717 & 0.550 & 0.604 & 0.595 \\
\hline IPP2 & $\mathbf{0 . 9 4 3}$ & 0.772 & 0.574 & 0.601 & 0.615 \\
\hline IPP3 & $\mathbf{0 . 9 0 9}$ & 0.819 & 0.529 & 0.599 & 0.579 \\
\hline SAT1 & 0.787 & $\mathbf{0 . 9 1 3}$ & 0.544 & 0.556 & 0.568 \\
\hline SAT2 & 0.782 & $\mathbf{0 . 9 2 9}$ & 0.533 & 0.581 & 0.568 \\
\hline SAT3 & 0.775 & $\mathbf{0 . 9 3 8}$ & 0.536 & 0.635 & 0.602 \\
\hline CNT1 & 0.549 & 0.482 & $\mathbf{0 . 8 4 3}$ & 0.658 & 0.663 \\
\hline CNT2 & 0.528 & 0.515 & $\mathbf{0 . 8 9 2}$ & 0.654 & 0.607 \\
\hline CNT3 & 0.466 & 0.492 & $\mathbf{0 . 8 6 2}$ & 0.563 & 0.558 \\
\hline CNT4 & 0.547 & 0.509 & $\mathbf{0 . 8 8 5}$ & 0.668 & 0.598 \\
\hline CNT5 & 0.529 & 0.526 & $\mathbf{0 . 8 7 4}$ & 0.695 & 0.600 \\
\hline PRS1 & 0.530 & 0.535 & 0.631 & $\mathbf{0 . 7 1 1}$ & 0.671 \\
\hline PRS2 & 0.525 & 0.518 & 0.588 & $\mathbf{0 . 8 3 9}$ & 0.625 \\
\hline PRS3 & 0.541 & 0.547 & 0.607 & $\mathbf{0 . 8 8 6}$ & 0.661 \\
\hline PRS4 & 0.543 & 0.514 & 0.623 & $\mathbf{0 . 8 4 3}$ & 0.621 \\
\hline PRS5 & 0.543 & 0.486 & 0.589 & $\mathbf{0 . 8 0 5}$ & 0.636 \\
\hline USB1 & 0.563 & 0.515 & 0.590 & 0.653 & $\mathbf{0 . 8 6 2}$ \\
\hline USB2 & 0.475 & 0.503 & 0.520 & 0.688 & $\mathbf{0 . 8 0 1}$ \\
\hline USB3 & 0.602 & 0.546 & 0.625 & 0.687 & $\mathbf{0 . 9 0 6}$ \\
\hline USB4 & 0.589 & 0.576 & 0.639 & 0.676 & $\mathbf{0 . 8 6 1}$ \\
\hline
\end{tabular}

TABLE II: CONSTRUCTS MEASUREMENT MODEL ASSESSMENT

\begin{tabular}{|c|c|c|c|c|c|}
\hline Constructs & Items & Loading & AVE & Composite Reliability & Cronbachs Alpha \\
\hline \multirow{4}{*}{$\begin{array}{l}\text { Individual } \\
\text { Performance } \\
\text { (IPP) }\end{array}$} & & & 0.838 & 0.940 & 0.903 \\
\hline & IPP1 & 0.894 & & & \\
\hline & IPP2 & 0.943 & & & \\
\hline & IPP3 & 0.909 & & & \\
\hline \multirow{4}{*}{$\begin{array}{l}\text { Satisfaction } \\
\text { (SAT) }\end{array}$} & & & 0.859 & 0.948 & 0.918 \\
\hline & SAT1 & 0.913 & & & \\
\hline & SAT2 & 0.929 & & & \\
\hline & SAT3 & 0.938 & & & \\
\hline \multirow{6}{*}{$\begin{array}{l}\text { Processing } \\
\text { (PRS) }\end{array}$} & & & 0.671 & 0.910 & 0.875 \\
\hline & PRS1 & 0.711 & & & \\
\hline & PRS2 & 0.839 & & & \\
\hline & PRS3 & 0.886 & & & \\
\hline & PRS4 & 0.843 & & & \\
\hline & PRS5 & 0.805 & & & \\
\hline \multirow{6}{*}{$\begin{array}{l}\text { Content } \\
\text { (CNT) }\end{array}$} & & & 0.759 & 0.940 & 0.921 \\
\hline & CNT1 & 0.843 & & & \\
\hline & CNT2 & 0.892 & & & \\
\hline & CNT3 & 0.862 & & & \\
\hline & CNT4 & 0.885 & & & \\
\hline & CNT5 & 0.874 & & & \\
\hline \multirow{5}{*}{$\begin{array}{l}\text { Usability } \\
\text { (USB) }\end{array}$} & & & 0.737 & 0.918 & 0.880 \\
\hline & USB 1 & 0.862 & & & \\
\hline & USB2 & 0.801 & & & \\
\hline & USB3 & 0.906 & & & \\
\hline & USB4 & 0.861 & & & \\
\hline
\end{tabular}

\section{B. Structural Model}

Fig. 2 demonstrates the test results of the three hypothesis executed by PLS. The overall assessment of the model is shown in Table IV, and all t-values are significant, which leads to conclude that three hypotheses are supported. The 
linear regression coefficients of perceived processing $(\beta=0.294, \quad p<0.000)$, content $(\beta=0.170, \quad p<0.000)$, and usability $(\beta=0.275, p<0.000)$ were all significant. The results provide evidence of the contribution of all of the factors to end users satisfaction in mandatory use systems. $R^{2}$ of (0.458) shows that about $45.8 \%$ of User satisfaction can be explained by perceived processing, usability, and content.

TABLE III: CORRELATION MATRIX OF CONSTRUCTS
\begin{tabular}{|c|c|c|c|c|c|c|} 
& $\mathbf{A V E}$ & CNT & IPP & PRS & SAT & USB \\
\hline CNT & $\mathbf{0 . 7 5 9}$ & $\mathbf{0 . 8 7 1}$ & & & & \\
\hline IPP & $\mathbf{0 . 8 3 8}$ & 0.601 & $\mathbf{0 . 9 1 6}$ & & & \\
\hline PRS & $\mathbf{0 . 6 7 1}$ & 0.744 & 0.656 & $\mathbf{0 . 8 1 9}$ & & \\
\hline SAT & $\mathbf{0 . 8 5 9}$ & 0.580 & 0.843 & 0.638 & $\mathbf{0 . 9 2 7}$ & \\
\hline USB & $\mathbf{0 . 7 3 7}$ & 0.694 & 0.651 & 0.788 & 0.625 & $\mathbf{0 . 8 5 8}$ \\
\hline
\end{tabular}
Items on the diagonal are square roots of AVE scores

TABLE IV: STRUCTURAL MODEL

\begin{tabular}{|c|c|c|c|c|c|c|}
\multirow{2}{*}{ Hypothesis } & Path Coefficient & Sample Mean & Standard Deviation & T Values & P Values & Result \\
\hline SAT -> IPP & 0.843 & 0.843 & 0.018 & 46.789 & 0.000 & Supported \\
\hline PRS -> SAT & 0.294 & 0.295 & 0.064 & 4.570 & 0.000 & Supported \\
\hline CNT -> SAT & 0.170 & 0.166 & 0.055 & 3.066 & 0.004 & Supported \\
\hline USB $>$ SAT & 0.275 & 0.276 & 0.073 & 3.763 & 0.000 & Supported \\
\hline
\end{tabular}

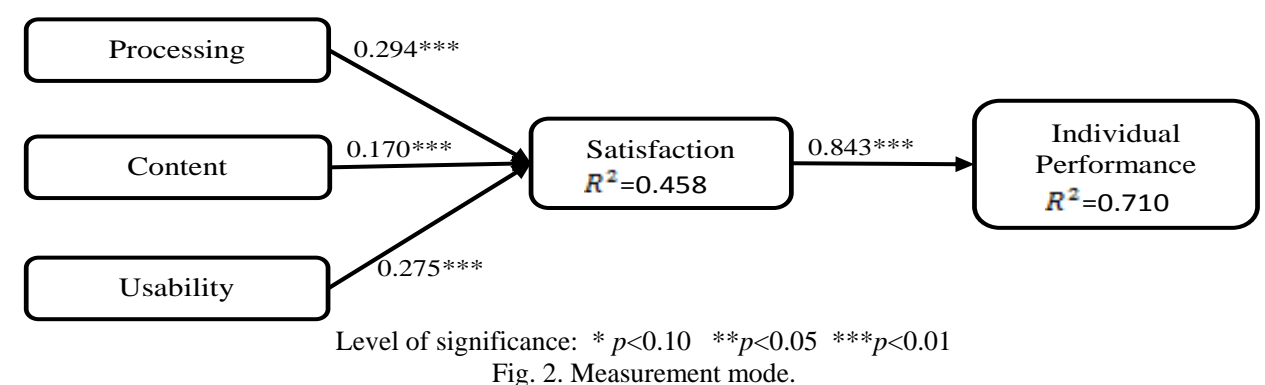

\section{DISCUSSION}

In addition to the impact of end-user satisfaction on individual performance, this study analyzes the impact of three factors: Processing, content, and usability on end-user's satisfaction in a mandatory use environment. All three variables are significant antecedents, and content plays the most important role in influencing user satisfaction. The results of this research are consistent with the findings of prior studies in IS. However, the impact of processing has mentioned in the literature to have a an effect on user satisfaction [41], content has a direct effect on user satisfaction in studies conducted by Maditinos and Theodoridis [47], additionally, usability showed a significant relationship with satisfaction in recent study by Belanche, Casaló [65], furthermore, studies by Guimaraes and Igbaria [53] and Hou [24] found that user satisfaction has strong direct influence on users performance. The results of this study prove the importance of processing, content and usability in enhancing and boosting end users satisfaction and as a result improving individual performance.

\section{LIMITATIONS AND FUTURE RESEARCH}

The main limitation of this study is the generalizability of the results; as the study framework is investigated in the context of developing country, e.g. Malaysia. It is plausible that developing countries are different from developed countries and undeveloped countries in terms of political, social, administrative, and economic characteristics, such as the nature of economy, the level of technology, and the quality of human resources etc. [66]. Those differences may have significant influence on the research model's results. To improve the generalizability of the results the replication of study framework in different contexts; such as, developing countries or undeveloped countries. Another limitation is the absence of some other important factors that might significantly influence end-user's satisfaction (e.g., trust, information quality). In the future, we wish to introduce these factors into the model in order to strengthen the explanatory power of this model.

\section{CONCLUSION}

This study develops a model to investigate the factors affecting end-user's satisfaction in mandatory use systems and the impact of end-user satisfaction on individual performance. The results demonstrate that three factors: perceived processing, content, and usability have significant positive and direct effects on ePerolehan's end-user's satisfaction which also has direct positive impact on individual performance. In general, the finding of this study enriches the knowledge of mandatory system use environment. Thus, the study provides suggestions into how to improve the mandated environment in the context of government e-Procurement system and the internal users, which is the employee of government agencies.

\section{APPENDIX}

\begin{tabular}{|c|c|}
\hline Construct & Items \\
\hline $\begin{array}{c}\text { Individual } \\
\text { performance }\end{array}$ & $\begin{array}{l}\text { IPI1: Using e-procurement system in my job helps me } \\
\text { to be more effective. } \\
\text { IPI2: Using e-procurement system in my job has a } \\
\text { positive impact on my productivity. }\end{array}$ \\
\hline
\end{tabular}




\begin{tabular}{|c|c|}
\hline & $\begin{array}{l}\text { IPI3: Using e-procurement system in my job } \\
\text { improves my job performance. }\end{array}$ \\
\hline \multirow[t]{2}{*}{$\begin{array}{c}\text { User's } \\
\text { Satisfaction }\end{array}$} & $\begin{array}{l}\text { SAT1: I am very pleased with using e-procurement } \\
\text { system in my work. } \\
\text { SAT2: My interaction with e-procurement system is } \\
\text { very satisfying. }\end{array}$ \\
\hline & $\begin{array}{l}\text { SAT3: All things considered, I am very satisfied with } \\
\text { e-procurement system. }\end{array}$ \\
\hline \multirow[t]{4}{*}{ Processing } & $\begin{array}{l}\text { PRS1: The e-procurement system is capable of } \\
\text { processing complex orders. }\end{array}$ \\
\hline & $\begin{array}{l}\text { PRS2: The e-procurement system is capable to ensure } \\
\text { that the right goods or services are delivered. } \\
\text { PRS3: The e-procurement system is capable to ensure } \\
\text { that orders arrive on time. }\end{array}$ \\
\hline & $\begin{array}{l}\text { PRS4: The e-procurement system is capable to ensure } \\
\text { that orders are processed quickly. }\end{array}$ \\
\hline & $\begin{array}{l}\text { PRS5: The e-procurement system is capable to ensure } \\
\text { that orders get to suppliers quickly. }\end{array}$ \\
\hline \multirow[t]{5}{*}{ Content } & $\begin{array}{l}\text { CNT1: The e-procurement system has the right } \\
\text { number of suppliers registered. }\end{array}$ \\
\hline & $\begin{array}{l}\text { CNT2: The e-procurement system has the right } \\
\text { number of catalogues uploaded. }\end{array}$ \\
\hline & $\begin{array}{l}\text { CNT3: The e-procurement system allows easy } \\
\text { searching for suppliers or items. }\end{array}$ \\
\hline & $\begin{array}{l}\text { CNT4: The e-procurement system provides the } \\
\text { accurate information I need. }\end{array}$ \\
\hline & $\begin{array}{l}\text { CNT5: The e-procurement system provides } \\
\text { information content that meets my needs. }\end{array}$ \\
\hline \multirow[t]{3}{*}{ Usability } & $\begin{array}{l}\text { USB1: The e-procurement system allows easy } \\
\text { navigation through the process. }\end{array}$ \\
\hline & $\begin{array}{l}\text { USB2: The e-procurement system is available at all } \\
\text { times. }\end{array}$ \\
\hline & $\begin{array}{l}\text { USB3: The e-procurement system is easy to use. } \\
\text { USB4: The e-procurement system is flexible to } \\
\text { interact with. }\end{array}$ \\
\hline
\end{tabular}

\section{REFERENCES}

[1] S. Goldfinch, "Pessimism, computer failure, and information systems development in the public sector," Public Administration Review, vol. 67, no. 5, pp. 917-929, 2007.

[2] P. Panda and G. Sahu, "E-Procurement implementation: critical analysis of success factors' impact on project outcome," SSRN, 2012

[3] E. Díez and B. S. McIntosh, "A review of the factors which influence the use and usefulness of information systems," Environmental Modelling \& Software, vol. 24, no. 5, pp. 588-602, 2009.

[4] W. H. DeLone and E. R. McLean, "Information systems success: the quest for the dependent variable," Information Systems Research, vol. 3 , no. 1, pp. 60-95, 1992.

[5] J. Y. L. Thong and C.-S. Yap, "Information systems effectiveness: A user satisfaction approach," Information Processing \& Management, vol. 32, no. 5, pp. 601-610, 1996.

[6] S. Hamilton and N. L. Chervany, "Evaluating information system effectiveness-Part I: Comparing evaluation approaches," MIS quarterly, pp. 55-69, 1981.

[7] L. Ball and R. Harris, "SMIS members: a membership analysis," MIS Quarterly, pp. 19-38, 1982.

[8] S. Petter and A. Fruhling, "Evaluating the success of an emergency response medical information system," International Journal of Medical Informatics, vol. 80, no. 7, pp. 480-489, 2011.

[9] H. C. Wang and Y. F. Chiu, "Assessing e-learning 2.0 system success," Computers \& Education, vol. 57, no. 2, pp. 1790-1800, 2011.

[10] S. Ainin, S. Bahri, and A. Ahmad, "Evaluating portal performance: a study of the national higher education fund corporation (ptptn) portal," Telematics and Informatics, vol. 29, no. 3, pp. 314-323, 2012.

[11] J. E. Bailey and S. W. Pearson, "Development of a tool for measuring and analyzing computer user satisfaction," Management Science, vol. 29 , no. 5 , pp. 530-545, 1983.

[12] M. Gelderman, "The relation between user satisfaction, usage of information systems and performance," Information \& Management, vol. 34, no. 1, pp. 11-18, 1998.

[13] M. A. Al-Khaldi and R. O. Wallace, "The influence of attitudes on personal computer utilization among knowledge workers: the case of
Saudi Arabia," Information \& Management, vol. 36, no. 4, pp. 185-204, 1999.

[14] H. Son et al., "Toward an understanding of construction professionals' acceptance of mobile computing devicesin South Korea: an extension of the technology acceptance model," Automation in Construction, vol. 28, pp. 82-90, 2012.

[15] M. A. Al-hawari and S. Mouakket, "The influence of technology acceptance model (tam) factors on students' e-satisfaction and e-retention within the context of uae e-learning," Education, Business and Society: Contemporary Middle Eastern Issues, vol. 3, no. 4, pp. 299-314, 2010.

[16] J. E. Klobas and T. J. McGill, "The role of involvement in learning management system success," Journal of Computing in Higher Education, vol. 22, no. 2, pp. 114-134, 2010.

[17] Y. K. Dwivedi et al., "RFID systems in libraries: an empirical examination of factors affecting system use and user satisfaction," International Journal of Information Management, vol. 33, no. 2, pp. 367-377, 2013.

[18] G. J. Udo, K. K. Bagchi, and P. J. Kirs, "Exploring the role of espoused values on e-service adoption: a comparative analysis of the us and nigerian users," Computers in Human Behavior, vol. 28, no. 5, pp. 1768-1781, 2012.

[19] J. S. Lim et al., "Testing alternative models of individuals' social media involvement and satisfaction," Computers in Human Behavior, vol. 29, no. 6, pp. 2816-2828, 2013.

[20] S. A. Brown et al., "Do I really have to? User acceptance of mandated technology," European Journal of Information Systems, vol. 11, no. 4, pp. 283-295, 2002.

[21] H. M. Abdelsalam, C. G. Reddick, and H. A. El Kadi, "Success and failure of local e-government projects: lessons learned from Egypt, in digital democracy: concepts, methodologies, tools, and applications," IGI Global, p. 183, 2012

[22] S. Ajami and Z. Bertiani, "Training and its impact on hospital information system (his) success," J. Inform. Tech. Softw. Eng., vol. 2, no. 112, p. 2, 2012.

[23] J. Ram, D. Corkindale, and M. L. Wu, "Implementation critical success factors (CSFs) for ERP: Do they contribute to implementation success and post-implementation performance?" International Journal of Production Economics, 2013.

[24] C. K. Hou, "Examining the effect of user satisfaction on system usage and individual performance with business intelligence systems: An empirical study of Taiwan's electronics industry," International Journal of Information Management, 2012.

[25] B. Kositanurit, K. M. Osei-Bryson, and O. Ngwenyama, "Re-examining information systems user performance: Using data mining to identify properties of IS that lead to highest levels of user performance," Expert Systems with Applications, vol. 38, no. 6, pp. 7041-7050, 2011.

[26] A. R. Hendrickson, K. Glorfeld, and T. P. Cronan, "On the repeated test-retest reliability of the end-user computing satisfaction instrument: A comment," Decision Sciences, vol. 25, no. 4, pp. 655-665, 1994.

[27] F. K. Y. Chan et al., "Modeling citizen satisfaction with mandatory adoption of an e-government technology," Journal of the Association for Information Systems, vol. 11, no. 10, pp. 519-549, 2010.

[28] Z. Lu, C. Wang, and H. Wang, "E-Government Satisfaction in Mandatory Adoption Environment," Research Journal of Applied Sciences, April 2012.

[29] N. Au, W. Ngai, and T. Cheng, "Extending the understanding of end user information systems satisfaction formation: an equitable needs fulfillment model approach," MIS Quarterly, vol. 32, no. 1, pp. 43-66, 2008.

[30] V. Venkatesh et al., "User acceptance of information technology: toward a unified view1," MIS Quarterly, vol. 27, no. 3, p. 425, 2003.

[31] W. H. Delone, "The DeLone and McLean model of information systems success: a ten-year update," Journal of Management Information Systems, vol. 19, no. 4, pp. 9-30, 2003.

[32] A. Brandon-Jones, "Perceived e-procurement quality: exploring and measuring the construct at a tactical level within the public sector, in Warwick business school," Dissertation, University of Warwick: Coventry, 2006.

[33] A. Brandon-Jones and S. Carey, "The impact of user-perceived e-procurement quality on system and contract compliance," International Journal of Operations \& Production Management, vol. 31, no. 3, pp. 274-296, 2011.

[34] K. A. Saeed, M. K. Malhotra, and V. Grover, "Examining the impact of interorganizational systems on process efficiency and sourcing leverage in buyer-supplier dyads," Decision Sciences, vol. 36, no. 3, pp. 365-396, 2005. 
[35] S. Croom and R. Johnston, "E-service: enhancing internal customer service through e-procurement," International Journal of Service Industry Management, vol. 14, no. 5, pp. 539-555, 2003.

[36] V. Sriram and R. Stump, "Information technology investments in purchasing: an empirical investigation of communications, relationship and performance outcomes," Omega, vol. 32, no. 1, pp. 41-55, 2004.

[37] A. Gunasekaran, and E. W. Ngai, "Adoption of e-procurement in Hong Kong: an empirical research," International Journal of Production Economics, vol. 113, no. 1, pp. 159-175, 2008.

[38] P. Wojciech and I. Zahir, "Analysing B2B electronic procurement benefits: information systems perspective," Journal of Enterprise Information Management, vol. 23, no. 4, pp. 559-579, 2010.

[39] A. Brandon-Jones, "Improving e-procurement compliance: The role of user perceptions," in Proc. POMS 20th Annual Conference, Orlando, Florida, U.S.A. 2009

[40] C. Subramaniam and M. J. Shaw, "A study of the value and impact of b2b e-commerce: the case of web-based procurement," International Journal of Electronic Commerce, vol. 6, no. 4, p. 19, 2002.

[41] H. Zhou and W. C. Benton, "Supply chain practice and information sharing," Journal of Operations Management, vol. 25, no. 6, pp. 1348-1365, 2007.

[42] C. A. Voss, "Rethinking paradigms of service: Service in a virtual environment," International Journal of Operations \& Production Management, vol. 23, no. 1, pp. 88-104, 2003.

[43] N. Gorla, T. M. Somers, and B. Wong, "Organizational impact of system quality, information quality, and service quality," The Journal of Strategic Information Systems, vol. 19, no. 3, pp. 207-228, 2010.

[44] L. R Smeltzer, "How to build an e-procurement strategy," Supply Chain Management Review, vol. 5. no. 3, pp. 76-83, 2001.

[45] B. Gu et al., "Competition among virtual communities and user valuation: The case of investing-related communities," Information Systems Research, vol. 18, no. 1, pp. 68-85, 2007.

[46] Y. Zheng, K. Zhao, and A. Stylianou, "The impacts of information quality and system quality on users' continuance intention in information-exchange virtual communities: an empirical investigation," Decision Support Systems, 2012.

[47] D. I. Maditinos and K. Theodoridis, "Satisfaction determinants in the Greek online shopping context," Information Technology \& People, vol. 23, no. 4, pp. 312-329, 2010.

[48] L. L. Berry, K. Seiders, and D. Grewal, "Understanding service convenience," The Journal of Marketing, pp. 1-17, 2002.

[49] R. G. Bias and D. J. Mayhew, Cost-Justifying Usability: An Update for an Internet Age, Morgan Kaufman, 2005.

[50] E. B. Kim and S. B. Eom, "Designing effective cyber store user interface," Industrial Management \& Data Systems, vol. 102, no. 5, pp 241-251, 2002.

[51] P. Zhang and D. F. Galletta, "Human computer interaction and management information systems: foundations," M.E. Sharpe, 2006.

[52] M. Igbaria and M. Tan, "The consequences of information technology acceptance on subsequent individual performance," Information \& Management, vol. 32, no. 3, pp. 113-121, 1997.

[53] T. Guimaraes and M. Igbaria, "Client/server system success: exploring the human side," Decision Sciences, vol. 28, no. 4, pp. 851-876, 1997.

[54] A. W .Gatian, "Is user satisfaction a valid measure of system effectiveness?" Information \& Management, vol. 26, no. 3, pp. 119-131, 1994.

[55] R. L. Hsiao and T. S. H. Teo, "Delivering on the promise of e-procurement," MISQ Executive, vol. 4, no. 3, pp. 343-360, 2005.

[56] M. Rask and H. Kragh, "Motives for e-marketplace participation: differences and similarities between buyers and suppliers," Electronic Markets, vol. 14, no. 4, pp. 270-283, 2004.
[57] EPerolehan Official Portal, Official Portal for Malaysian Government $\begin{array}{lll}\text { Procurement. (2013). } & \text { [Online]. Available: }\end{array}$ http://home.eperolehan.gov.my/v2/

[58] Z. A. Rashid, "E-Perolehan-A breakthrough for e-commerce in the malaysian government," Public Sector Management Review, vol. 1, no. 1, pp. 20-24, 2007.

[59] IOS Press, "Global information technology report," Journal of e-Governance, vol. 34, pp. 114-118, 2011.

[60] P. Palvia, "The role of trust in e-commerce relational exchange: A unified model," Information \&amp; Management, vol. 46, no. 4, pp. 213-220, 2009.

[61] B. H. Wixom and P. A. Todd, "A theoretical integration of user satisfaction and technology acceptance," Information Systems Research, vol. 16, no. 1, pp. 85-102, 2005

[62] F. D. Davis, "Perceived usefulness, perceived ease of use, and user acceptance of information technology," MIS Quarterly, vol. 13, no. 3, pp. 319-340, 1989.

[63] W. W. Chin, "Issues and opinion on structural equation modeling, in MIS Quarterly," MIS Quarterly \& the Society for Information Management, p. 1, 1998.

[64] J. F. Hair et al., "A primer on partial least squares structural equation modeling (PLS-SEM)," SAGE Publications, 2014.

[65] D. Belanche, L. V. Casaló, and M. Guinalíu, "Website usability, consumer satisfaction and the intention to use a website: The moderating effect of perceived risk," Journal of Retailing and Consumer Services, vol. 19, no. 1, pp. 124-132, 2012.

[66] S. Palekar, Development Administration, PHI Learning Pvt. Ltd, 2012.

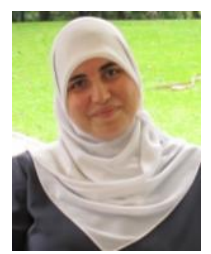

Manal M. N. Sharabati is currently pursuing her doctoral studies under the Operations and Management Information Systems Department, Faculty of Business and Accountancy, University of Malays, Malaysia. Her research interests include e-business, e-government and e-learning.

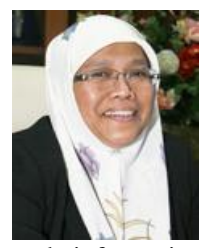

Ainin Sulaiman is a lecturer in the Operation and Management Information Systems Department, Faculty of Business and Accountancy, University of Malaya, Malaysia. Her areas of expertise are information technology management, e-commerce and management information systems. She is actively involved in research on e-commerce, digital divide and information systems performance measurement on Malaysian organizations.

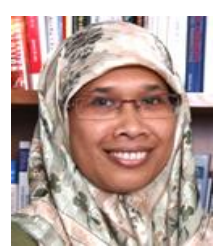

Noor Akma Binti Mohd Salleh is a lecturer in the Operation and Management Information Systems Department, Faculty of Business and Accountancy, University of Malaya, Malaysia. Her areas of expertise are management information system, information systems adoption behavior, information systems performance and information systems capabilities. 